\title{
Determination of free heavy metal ion concentrations in soils around a cadmium rich zinc deposit
}

\author{
Li YI, ${ }^{1,2}$ Yetang Hong, ${ }^{1}$ DUOJUn WANG ${ }^{3 *}$ and YongXuAn Zhu ${ }^{1}$ \\ ${ }^{1}$ The State Key Laboratory of Environmental Geochemistry, Institute of Geochemistry, Chinese Academy of Science, \\ Guizhou, Guiyang 550002 China \\ ${ }^{2}$ Institute of Earthquake Science, China Earthquake Administration, Beijing 100036 China \\ ${ }^{3}$ State Key Laboratory of Earthquake Dynamics, Institute of Geology, China Earthquake Administration, Beijing 100029 China
}

(Received June 13, 2006; Accepted April 2, 2007)

\begin{abstract}
The study of heavy metal speciation is of interest for the evaluation of their ecotoxicological risk. Free heavy metal ion concentrations of $\mathrm{Cu}^{2+}, \mathrm{Zn}^{2+}, \mathrm{Ni}^{2+}$ and $\mathrm{Cd}^{2+}$ were studied at different soil to soil solution ratio (SSR) to discuss metal bioavailability and toxicity in circumstance. The samples were collected from two farmed soils, impacted by a cadmium rich zinc deposit, Guizhou, China. One is near a bridge (QBT for short), which is $15 \mathrm{~km}$ away from smelter and is regarded as polluted by fly ash from smelter, the other is located $300 \mathrm{~m}$ away from a smelting factory (BXT for short), and it is polluted badly by waste water from smelter. To determine the free heavy metal ion concentration, Donnan Membrane Technique (DMT) and ECOSAT program were used. The concentrations of free copper and zinc ions in QBT and all studied metal ions in BXT were nearly in direct ratio with the soil to soil solution ratio, and they increased with the increasing of SSR. The variational trends of the concentrations of free nickel and cadmium ions in QBT were contrary to those of copper and zinc ions. The measured and predicted results were compared and they agreed with each other. Individual sorbents contribution to metal binding was also predicted. The results suggest soil organic matter is the most important sorbents in the two soils, and hydrous ferric oxide takes the second place.
\end{abstract}

Keywords: soil, free heavy metal ion concentration, Donnan Membrane Technique (DMT), ECOSAT program, contribution

\section{INTRODUCTION}

During recent several decades soil is polluted more and more serious by heavy metals because of mining, smelting, irrigating with sewerage and some other human activities. These heavy metals may adversely affect soil ecology, agricultural production or product quality, and ground water quality, and will ultimately harm to heath of mankind by food chain. These effects are closely related to the biological availability of heavy metals, which in turn are controlled by the metal ion speciation in the soil (Davis et al., 1992; Katbata-Pendias, 1993; Alloway, 1995). Metals exist in a number of different soluble and particulate forms, which influence their mobility and bioavailability (Ge et al., 2005), and free metal activity has been shown to be the key factor in determining metal bioavailability and toxicity in most circumstance (Parker and Pedler, 1996; Weng et al., 2001a; Cancès et al., 2003). Therefore, measuring of free metal ion concentrations in soil solution becomes important.

*Corresponding author (e-mail: duojunwang@hotmail.com) Copyright $@ 2007$ by The Geochemical Society of Japan.
The free metal ion concentration not only depends on the total metal content in soils, but also on the metal species that exist in the soil. In addition, some environmental conditions (e.g., pH, concentration of competing ions, concentration of complexing ligands in solution, and the soil colloid) and characteristics of organism in soil may play an important role (Temminghoff et al., 2000). Hereto there are a number of methods determining the free metal ion concentration, but each method has its advantages and limitations (Florence, 1986; Apte and Batley, 1995; Mota and Correia dos Santos, 1995). The ion selective electrometry (ISE) is simple and cheap, and can directly measure the free metal ion concentration in solution (Mota and Correia dos Santos, 1995). But its detection limit is high, and other metal ions in solution interferes measurement. The voltammetric methods could measure heavy metal speciation at small concentration $\left(10^{-8}-10^{-11} \mathrm{~mol} /\right.$ L) at first hand (Mota and Correia dos Santos, 1995). But the reaction equilibrium is disturbed by the current applied in the electrolytic cell, and this problem is hardly avoided (Nordstrom, 1996). The method of competitive chelation could achieve free heavy metal ions concentrations directly with good sensitivity, while chelates attain equilibrium with soils very slowly (Norvell and Lindsay, 1969, 1972; Workman and Lindsay, 1990). The cation 
Table 1. Soil characteristics and total metal content extracted with 2 mol/L $\mathrm{HNO}_{3}$

\begin{tabular}{|c|c|c|c|c|c|c|c|c|c|c|}
\hline \multirow[t]{2}{*}{ Sample } & \multirow[t]{2}{*}{$\mathrm{pH}$} & \multirow{2}{*}{$\begin{array}{c}\mathrm{CEC}-\mathrm{BaCl}_{2} \\
(\mathrm{mmol} / \mathrm{kg})\end{array}$} & \multirow{2}{*}{$\begin{array}{l}\mathrm{OM} \\
(\%)\end{array}$} & \multirow{2}{*}{$\begin{array}{l}\text { Clay }(\%) \\
(<2 \mu \mathrm{m})\end{array}$} & \multirow{2}{*}{$\begin{array}{l}\mathrm{Fe}-\mathrm{ox} \\
(\mathrm{g} / \mathrm{kg})\end{array}$} & \multirow{2}{*}{$\begin{array}{c}\mathrm{Fe}-\mathrm{DCB} \\
(\mathrm{g} / \mathrm{kg})\end{array}$} & \multicolumn{4}{|c|}{ Total metal content extracted with $2 \mathrm{~mol} / \mathrm{L} \mathrm{HNO}_{3}(\mu \mathrm{mol} / \mathrm{kg})$} \\
\hline & & & & & & & $\mathrm{Cu}$ & $\mathrm{Zn}$ & $\mathrm{Ni}$ & $\mathrm{Cd}$ \\
\hline QBT & $7.59 \pm 0.02$ & $11.89 \pm 0.51$ & $4.82 \pm 0.07$ & $2.3 \pm 0.2$ & $5.05 \pm 0.08$ & $19.57 \pm 0.41$ & $1153.91 \pm 28.36$ & $13137.88 \pm 274.06$ & $168.64 \pm 1.44$ & $46.15 \pm 0.24$ \\
\hline BXT & $7.51 \pm 0.01$ & $13.14 \pm 0.39$ & $4.90 \pm 0.09$ & $2.5 \pm 0.3$ & $5.00 \pm 0.06$ & $47.23 \pm 0.82$ & $3209.34 \pm 34.25$ & $38648.02 \pm 768.42$ & $411.28 \pm 2.97$ & $538.06 \pm 1.87$ \\
\hline
\end{tabular}

Table 2. Ion exchange membrane properties

\begin{tabular}{ccccccc}
\hline Color & $\begin{array}{c}\text { Thickness } \\
(\mathrm{mm})\end{array}$ & $\begin{array}{c}\text { Exchange capacity } \\
(\mathrm{mol} / \mathrm{kg})\end{array}$ & $\begin{array}{c}\text { Water content } \\
(\%)\end{array}$ & $\begin{array}{c}\text { Surface resistance } \\
\left(\mu \mathrm{cm}^{-2}\right)\end{array}$ & $\begin{array}{c}\text { Transference } \\
(\%)\end{array}$ & $\begin{array}{c}\text { Demolishment intensity } \\
(\mathrm{MPa})\end{array}$ \\
\hline Black & $0.11-0.13$ & $\geq 1.6$ & $\geq 22$ & $\leq 8$ & $\geq 95$ & $\geq 1.5$ \\
\hline
\end{tabular}

exchange resin method can measure several free metal ion concentrations at the same time (Apte and Batley, 1995). But before the method was used, some condition required knowing. It included the adsorption properties of selected resin and the soil solution composition (Fotovat and Naidu, 1997). This make the method complicated.

In recent, a procedure has been developed, named as Donnan membrane technique, which is able to measure several free metal ion concentrations at the same time, moreover, all the metals did not interfere each other, and it minimizes the disturbance of substrate (Temminghoff et al., 2000). It has been successfully used to measured free metal ion concentration in natural waters (Weng et al., 2002; Liesbeth et al., 2006) and soils (Weng et al., 2001a, b; Weng et al., 2002; Cancès et al., 2003) at different $\mathrm{pH}$ for assessment of water and soil quality. It was also used for investigating the availability of nutrients in animal slurry for plant uptake (van der Stelt et al., 2005). The objective of this study was to know the heavy metal bioavailability and chemical speciation in the studied soil, and assess the risks posed by contaminated soils. We apply Donnan Membrane Technique to measure the free $\mathrm{Cu}^{2+}, \mathrm{Zn}^{2+}, \mathrm{Ni}^{2+}$ and $\mathrm{Cd}^{2+}$ concentrations in two farmed soils at different SSR, which were compared with those predicted using ECOSAT program. Individual sorbents contribution to metal binding was also predicted. The relative important soil sorbents include soil organic matter, iron hydroxides and clay.

\section{Methodology}

\section{Soil sample}

Two farmed soils were collected from the district of a cadmium rich zinc deposit, Guizhou, China. One is near a bridge (QBT for short), which is $15 \mathrm{~km}$ away from smelter and is regarded as polluted by fly ash from smelter, the other is located $300 \mathrm{~m}$ away from a smelting factory
(BXT for short), and BXT is polluted badly by waste water from smelter (Ye and Liu, 2001; Liu et al., 2004). The samples have been oriented to collect a representative topsoil $(0-20 \mathrm{~cm})$ sample of $20 \mathrm{~kg}$ in closed plastic bags. After mixed, the samples were dried and sieved at $2 \mathrm{~mm}$. All the experimental studies are done on this fraction $(<2$ $\mathrm{mm}$ ). The different bulk soil chemical properties and total metal content extracted with $2 \mathrm{~mol} / \mathrm{L} \mathrm{HNO}_{3}$ are given in Table 1 .

\section{Donnan membrane technique}

Donnan membrane technique is based on theory of Donnan equilibrium. A semipermeable cation exchange membrane separates the reaction cell into two parts: the donor cell and the acceptor cell. The ion exchange membrane properties used were shown in Table 2. Donor solution was composed of background electrolyte and studied soils. Before experiment the solution in the donor cell has reached equilibrium with soil samples. Acceptor solution includes only background electrolyte solution. Peristaltic pumps were used to circle the donor and acceptor solution. The two solutions will diffuse mutually in a subminiature cell through cation exchange membrane, and at last equilibrium will be attained. When Donnan membrane equilibrium is reached, the concentration ratios of the metal ions in the donor solution and in the acceptor solution are equal (Temminghoff et al., 1997).

$$
\left(C_{i, \text { don }} / C_{i, a c c}\right)^{1 / Z_{i}}=\left(C_{j, \text { don }} / C_{j, a c c}\right)^{1 / Z_{j}},
$$

where $C_{i, d o n}$ and $C_{i, a c c}$ are the concentrations of the "free" cation $i$ in the donor and acceptor solution, and $Z_{i}$ is its charge, and $C_{j, d o n}, C_{j, a c c}$ and $Z_{j}$ are the same for cation $j$. Assuming that cation $j$ almost can not form complexes with ligands, the total concentration is similar to the "free" cation concentration (Temminghoff et al., 2000; Weng et al., 2001b). Potassium was selected in this study. In the 
experiment the total volume of the acceptor solution is $15 \mathrm{ml}$, whereas that of the donor solution is $250 \mathrm{ml}$. A large donor volume is used to guarantee that metals diffused to the acceptor solution are very small as compared to the total metal concentration in the donor solution, to ensure that changes in the metal concentration will be negligible. After attaining Donnan membrane equilibrium, the donor solutions were sampled for $\left[\mathrm{K}^{+}\right]$, and acceptor solutions for both $\left[\mathrm{K}^{+}\right]$and $\left[\mathrm{M}^{2+}\right]$. $\left[\mathrm{K}^{+}\right]$was measured by AAS (PE-AA800), and $\left[\mathrm{M}^{2+}\right]$ were measured by ICP-MS.

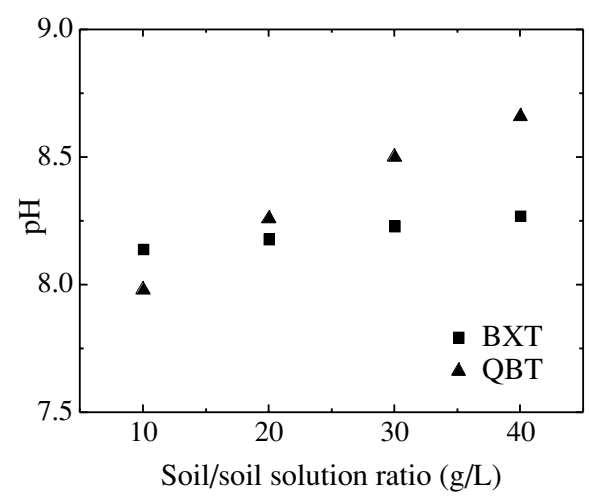

Fig. 1. pH measured as function of soil to soil solution ratio.

\section{Modelling}

ECOSAT is a computer program which can be used to calculate the chemical equilibrium composition of soilwater systems, depending on speciation and transport (Keizer and Van Riemsdijk, 2002). The multisurface model considers soils as a set of independent sorption surfaces, i.e., organic matter, iron hydroxides, and clay. The metal speciation was predicted using models of adsorption and ion exchange for each sorbent (Weng et al., 2001b).

Humic acid was used as an anlogue for the reactive soil organic matter (SOM). The Non Ideal Competitive Adsorption Donnan (NICA-Donna) model is one of the most advanced models for competitive metal ion binding to humic substances. This model includes site binding heterogeneity, electrostatic effects, competitive binding, and ion specific non-ideality, so it was chosen for metal binding to soil organic matter (Kinniburgh et al., 1999; Koopal et al., 2005). There are two types of iron hydroxides in soil, amorphous and crystalline ferric oxides. In the model they were assumed as hydrous ferric oxide (HFO) and goethite, respectively. Metal binding to HFO was described by a two site surface complexation diffuse double layer (DDL) model. The adsorption of metals to goethite was calculated with the charge distribution multisite complexation (CD-MUSIC) model (Dzombak and
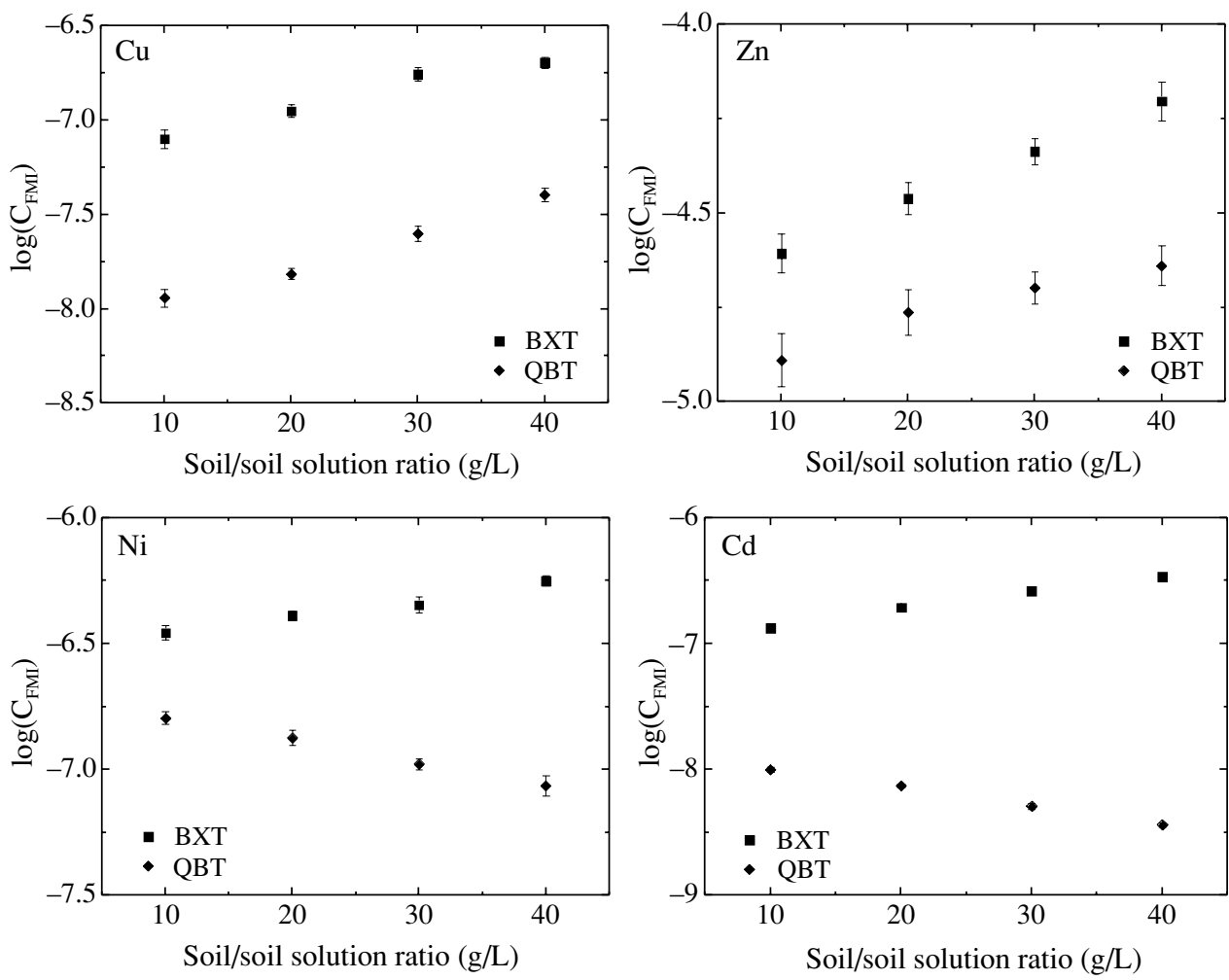

Fig. 2. Free heavy metal ion concentrations measured as function of soil to soil solution ratio. 

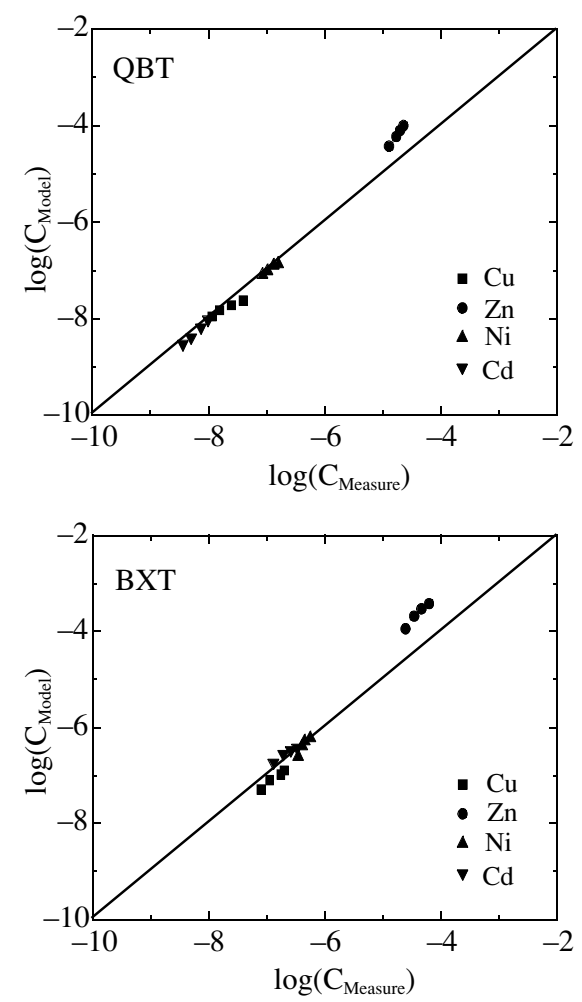

Fig. 3. Comparison of measured and modeled free metal ion concentrations. - : one to one line.
Morel, 1990; Hiemstra and Van Riemsdijk, 1996, 1999). $\mathrm{X}$-ray diffraction shows that most clay silicate is illite in the two studied soils (Yi, 2005), so illite was taken as a representative in the model. Its binding metals was model through a Donnan approach (Weng et al., 2001b).

\section{RESULTS AND DISCUSSION}

\section{Analytical results}

The $\mathrm{Cu}$ and $\mathrm{Zn}$ transporting through the selected membrane as function of time had been tested, and Donnan equilibrium reached after about $24 \mathrm{~h}$ (Yi et al., 2005). The free metal ion concentrations of $\mathrm{Cu}, \mathrm{Zn}, \mathrm{Ni}$ and $\mathrm{Cd}$ in two soils were measured using Donnan Membrane Technique (DMT) at different soil to soil solution ratio. We can know pH varieties with SSR from Fig. 1, and Fig. 2 shows the free metal ion concentrations are almost in line with SSR.

The $\mathrm{Cu}^{2+}$ concentration measured ranges from $10^{-8}$ to $10^{-6.7} \mathrm{~mol} / \mathrm{L}, \mathrm{Zn}^{2+}$ concentration varies from $10^{-4.9}$ to $10^{-4.2} \mathrm{~mol} / \mathrm{L}, \mathrm{Ni}^{2+}$ concentration is between $10^{-7.1}$ to $10^{-6.2} \mathrm{~mol} / \mathrm{L}$, and $\mathrm{Cd}^{2+}$ concentration measured varies from $10^{-8.5}$ to $10^{-6.4} \mathrm{~mol} / \mathrm{L}$. In general, the free metal ion concentrations increases with increasing SSR, except for the concentrations of free nickel and cadmium ions in QBT. Their variational tendencies are contrary to the oth-
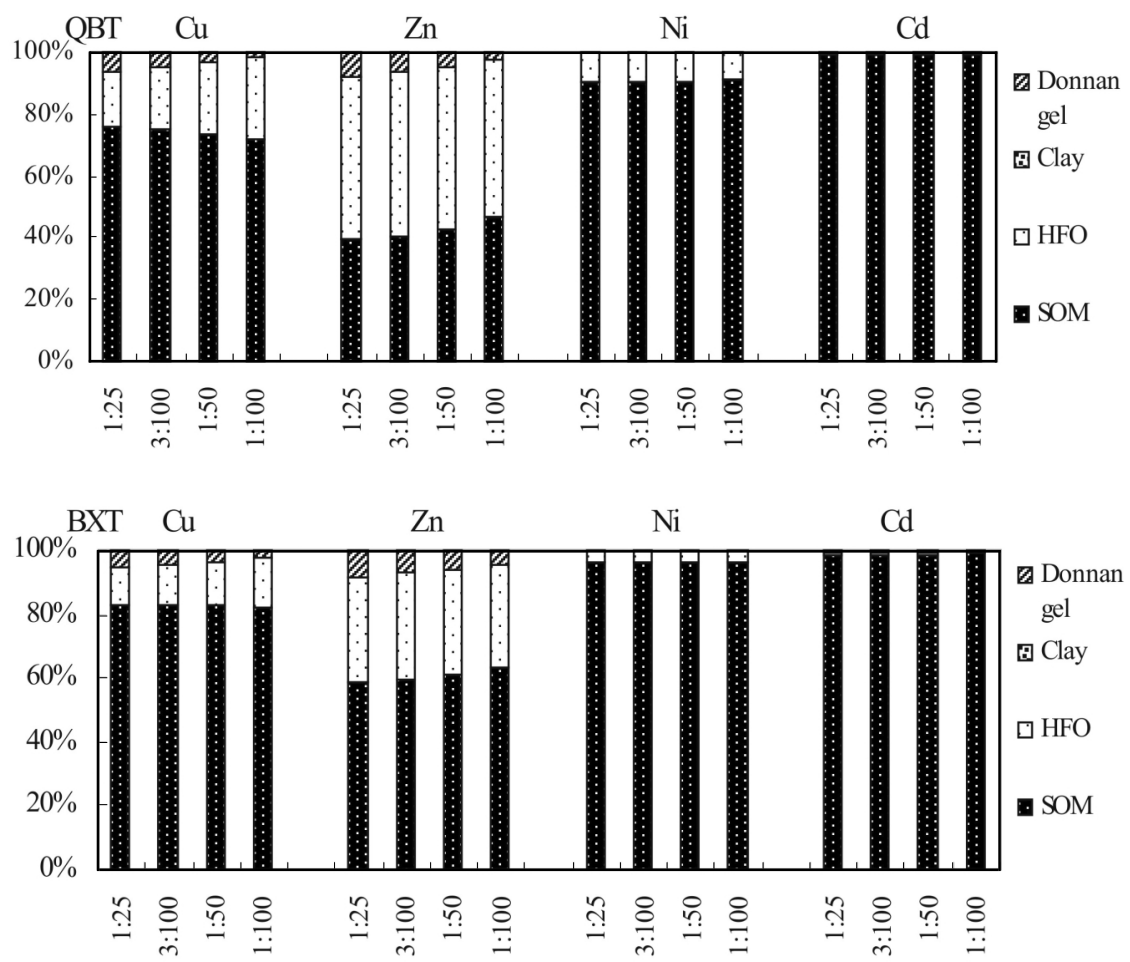

Fig. 4. Calculated metals distributions in soils. 
ers. They decrease while SSR increases. With increasing dilution, pH of QBT decreased sharply (Fig. 1). It is widely accepted that $\mathrm{pH}$ is one of the key factor in affecting the metal adsorption. Moreover, according to the calculated metals distributions in soils, the contributions to metal binding of soil organic matter reduced with the decreasing SSR. The adverse variational tendencies of free nickel and cadmium ions in QBT were mostly probably the result of $\mathrm{Ni}^{2+}$ and $\mathrm{Cd}^{2+}$ release from soil organic matter. Among these metals, $\mathrm{Cu}$ has the lowest free ion concentration in comparison with total $\mathrm{Cu}$. Less than $0.25 \%$ of the total $2 \mathrm{~mol} / \mathrm{L} \mathrm{HNO}_{3}$ extractable $\mathrm{Cu}$ exists as free $\mathrm{Cu}^{2+}$, whereas for $\mathrm{Zn}$, the soil has much lower affinity for $\mathrm{Zn}$, so it exceeds $4.0 \%$.

Comparison between free heavy metal activity predicted and measured

Not only the free heavy metal ion concentrations in the two soils were measured, but also they were modeled. Prediction was done with the data given in Table 1. In Fig. 3, the predicted free $\mathrm{Cu}^{2+}, \mathrm{Zn}^{2+}, \mathrm{Ni}^{2+}$ and $\mathrm{Cd}^{2+}$ concentrations using ECOSAT program are compared to those measured. They are in good agreement, except for zinc ion. The errors of free $\mathrm{Cu}^{2+}, \mathrm{Zn}^{2+}, \mathrm{Ni}^{2+}$ and $\mathrm{Cd}^{2+}$ concentrations are within $0.2,0.8,0.1$ and $0.15 \mathrm{log}$-unit, respectively. Compared to their free concentration ranges, such errors are reasonable, except for $\mathrm{Zn}^{2+}$. Free $\mathrm{Zn}^{2+}$ concentration nearly went beyond the detection limit of the ICPMS, so its error was much higher. But it is still considered succeeding well according to some other results (Weng et al., 2001b).

\section{Individual sorbents contribution to metal binding}

Contributions of soil sorbents to the heavy metals adsorptions were modeled through ECOSAT at different SSR. The sorbents in soil included soil organic matter, iron hydroxides, clay and the Donnan gel of soil organic matter.

Figure 4 showed that the contribution bound to clay is very little, and could be neglected. Copper is mainly contributed in soil organic matter, and accounting $80 \%$. With the decreasing of SSR, the contributions of copper bounded to soil organic matter and the Donnan gel of soil organic matter decrease slowly, but the contribution bounded to iron hydroxides increases. Zinc is mainly contributed in soil organic matter and iron hydroxides, and accounting $40 \%$ respectively. As SSR decreases, the contribution of zinc bounded to soil organic matter increases little, and the contribution bounded to iron hydroxides is hardly changed, but the Donnan gel of soil organic matter decreases slowly. Nickel is mainly bounded to the soil organic matter and iron hydroxides, and cadmium is almost bounded to the soil organic matter. The contributions of nickel and cadmium are affected little by SSR.
Such results denote soil organic matter is the most important sorbents in the two soils, and hydrous ferric oxide takes second place.

\section{Conclusions}

The free heavy metal ion concentrations of $\mathrm{Cu}^{2+}, \mathrm{Zn}^{2+}$, $\mathrm{Ni}^{2+}$ and $\mathrm{Cd}^{2+}$ were measured with Donnan membrane technique and modeled through ECOSAT at different SSR, and they were consistent with each other. They are usable tool for assessing the risks posed by contaminated soils. In the studied soils free metal ion concentrations increases with increasing SSR, except for the concentrations of free nickel and cadmium ions in QBT. They decrease while SSR increases. $\mathrm{Ni}^{2+}$ and $\mathrm{Cd}^{2+}$ released from soil organic matter may be response for the result, which was intensified by the modeled contributions of soil sorbents to the heavy metals adsorptions. We concluded that enlarging the quantity of irrigation will reduce the risks posed by the contaminated soils.

According to the modeled contributions of heavy metals, most metals were adsorbed by soil organic matter and hydrous ferric oxide in the two soils, accounting to $80 \%$ or more. So the additives comprising much organic matter and hydrous ferric oxide will immobilize the heavy metals contained in the contaminated soils, then the bioavailability of heavy metal in the soil will decrease. This will be a good remediation for the studied soils.

Acknowledgments-This research project was financially supported by the National Natural Science Foundation of China (Grant No. 40231007).

\section{REFERENCES}

Alloway, B. J. (1995) Heavy Metals in Soils. Blackie Academic and Professional, Glasgow, Scotland, 368 pp.

Apte, S. C. and Batley, G. E. (1995) Trace metal speciation of labile chemical species in natural waters and sediments: nonelectrochemical approaches. Metal Speciation and Bioavailability in Aquatic Systems (Tessier, A. and Turner, D. R., eds.), 256-306, John Wiley \& Sons, Chichester.

Cancès, B., Ponthieu, M., Castrec-Pouelle, M., Aubry, E. and Benedetti, M. F. (2003) Metal ions speciation in a soil and its solution: experimental data and model results. Geoderma 113, 341-355.

Davis, A., Ruby, M. V. and Bergstom, P. D. (1992) Bioavailability of arsenic and lead in soils from the Butte, Montana, minting district. Environ. Sci. Technol. 26, 461468.

Dzombak, D. A. and Morel, F. M. M. (1990) Surface Complexation Modelling: Hydrous Ferric Oxide. Wiley, New York.

Florence, T. M. (1986) Electrochemical approaches to trace element speciation in waters: a review. Analyst 111, 489-505.

Fotovat, A. and Naidu, R. (1997) Ion exchange resin and 
MINTEQA2 speciation of $\mathrm{Zn}$ and $\mathrm{Cu}$ in alkaline sodic and acidic soil extracts. Australian J. Soil Res. 35, 711-726.

Ge, Y., MacDonald, D., Sauvoé, S. and Hendershot, W. (2005) Modeling of $\mathrm{Cd}$ and $\mathrm{Pb}$ speciation in soil solutions by WinHumic V and NICA-Donnan model. Environ. Model. Softw. 20, 353-359.

Hiemstra, T. and Van Riemsdijk, W. H. (1996) A surface structural approach to ion adsorption: the Charge Distribution (CD) Model. J. Colloid Interface Sci. 179, 488-508.

Hiemstra, T. and Van Riemsdijk, W. H. (1999) Surface structural ion adsorption modeling of competitive binding of oxyanions by metal (hydr)oxides. J. Colloid Interface Sci. 210, 182-193.

Katbata-Pendias, A. (1993) Behavioural properties of trace metals in soils. Appl. Geochem. 2, 3-9.

Keizer, M. G. and Van Riemsdijk, W. H. (2002) ECOSAT: a computer program for the calculation of speciation and transport in soil-water systems, version 4.7 for Windows, User's Manual. The Netherlands.

Kinniburgh, D. G., Van Riemsdijk, W. H., Koopal, L. K., Borkovec, M., Benedetti, M. F. and Avena, M. J. (1999) Ion binding to natural organic matter: competition, heterogeneity, stoichiometry and thermodynamic consistency. Colloids and Surfaces A: Physicochemical and Engineering Aspects 151, 147-166.

Koopal, L. K., Saito, T., Pinheiro, J. P. and Van Riemsdijk, W. H. (2005) Ion binding to natural organic matter: General considerations and the NICA-Donnan model. Colloids and Surfaces A: Physicochemical and Engineering Aspects 265(1-3), 40-54.

Liesbeth, V. L., Erik, S., Fien, D., Colin, J. and Karel, A. C. D. S. (2006) Speciation of nickel in surface waters measured with the Donnan membrane technique. Anal. Chim. Acta 578, 195-202.

Liu, T., Zhang, Q., Ye, L. and Shao, S.-X. (2004) Discovery of primary greenockite in nature, as exemplified by the Niujiaotang cadmium-zinc deposit, Guizhou. Acta Mineralogica Sinica 24(2), 191-196 (in Chinese).

Mota, A. M. and Correia dos Santos, M. M. (1995) Trace metal speciation of labile chemical species in natural waters: electrochemical methods. Metal Speciation and Bioavailability in Aquatic Systems (Tessier, A. and Turner, D. R., eds.), 205-258, John Wiley \& Sons, Chichester.

Nordstrom, D. K. (1996) Trace metal speciation in natural waters: computational vs. analytical. Water Air Soil Pollut. 90, 257-267.

Norvell, W. A. and Lindsay, W. L. (1969) Reactions of EDTA complexes of $\mathrm{Fe}, \mathrm{Zn}, \mathrm{Mn}$, and $\mathrm{Cu}$ with soil. Soil Science
Society of America Proceedings 33, 86-91.

Norvell, W. A. and Lindsay, W. L. (1972) Reactions of DTPA complexes of iron, zinc, copper, and manganese with soil. Soil Science Society of America Proceedings 36, 773-788.

Parker, D. R. and Pedler, J. F. (1996) Reevaluation of the freeion activity model of trace metal availability to higher plants. Plant and Soil 196, 223-228.

Temminghoff, E. J. M., Van der Zee, S. E. A. T. M. and De Haan, F. A. M. (1997) Copper mobility in a copper-contaminated sandy soil as affected by $\mathrm{pH}$ and solid and dissolved organic matter. Environ. Sci. Tech. 31, 1109-1115.

Temminghoff, E. J. M., Plette, A. C. C., Van Eck, R. and Van Riemsdijk, W. H. (2000) Determination of the chemical speciation of trace metals in aqueous systems by Wageningen Donnan Membrane Technique. Anal. Chim. Acta 417, 149-157.

van der Stelt, B., Temminghoff, E. J. M. and Van Riemsdijk, W. H. (2005) Measurement of ion speciation in animal slurries using the Donnan Membrane Technique. Anal. Chim. Acta 552, 135-140.

Weng, L., Temminghoff, E. J. M. and Van Riemsdijk, W. H. (2001a) Determination of the free ion concentration of trace metals in soil solution using a soil column Donnan membrane technique. Eur. J. Soil Sci. 52, 629-637.

Weng, L., Temminghoff, E. J. M. and Van Riemsdijk, W. H. (2001b) Contribution of individual sorbents to the control of heavy metal activity in sandy soil. Environ. Sci. Technol. 35, 4436-4443.

Weng, L., Temminghoff, E. J. M. and Van Riemsdijk, W. H. (2002) Aluminum speciation in natural waters: measurement using Donnan membrane technique and modeling using NICA-Donnan. Water Res. 36, 4215-4226.

Workman, S. M. and Lindsay, W. L. (1990) Estimating divalent cadmium activities measured in arid-zone soils using competitive chelation. Soil Sci. Soc. Am. J. 54, 987-993.

Ye, L. and Liu, T. (2001) Distribution features and existing forms of cadmium in the Niujiaotang Cd-rich zinc deposit, Guizhou, China. Acta Mineralogica Sinica 21(1), 115-118 (in Chinese).

Yi, L. (2005) Determining and modeling the free concentrations of heavy metals ions in soil and controlling the pollution in situ. Dr. Sci. thesis, Graduate School of Chinese Academy of Science, Beijing, 52 pp. (in Chinese).

Yi, L., Hong, Y., Weng, L. and Zhu, Y. (2005) Measurement of free heavy metal ion concentrations in soils using Donnan membrane technique. Chinese Journal of Geochemistry 24(2), 184-188. 